The Journal of Academic Librarianship, 2002, Vol. 28, No. 4, pp. 191-196.

Print ISSN: 0099-1333 Online ISSN: 1879-1999

doi:10.1016/S0099-1333(02)00282-3

http://elsevier.com/wps/find/homepage.cws_home

http://www.sciencedirect.com/science/journal/00991333

http://www.sciencedirect.com/science/article/B6W50-45YJBP2-3/2/5fe2b59ec72784b1a26587190b31f037

(C) 2002 Elsevier Ltd. All rights reserved.

\title{
Connecting the Dots: Limited English Proficiency, Second Language Learning Theories, and Information Literacy Instruction
}

\author{
by Miriam Conteh-Morgan
}

Miriam Conteh-Morgan is Assistant Professor and Distinguished Linguistics and French Bibliographer

Librarians who teach students with limited English proficiency have discussed various barriers limiting effective learning. This article shows how applying second language acquisition theories and teaching practices derived from them can significantly impact outcomes of information literacy instruction.

In the professional literature and electronic discussion groups, such as BI-L, the library experience of limited English proficient (LEP) ${ }^{1}$ students is a regularly discussed topic. With regard to instruction, the most attention has been paid to the various barriers that affect their use of the library and, more recently, to culture-dependent learning styles. This is because, according to Diane DiMartino and Lucinda Zoe, ${ }^{2}$ many librarians agree that:

Language, cultural and technological barriers, and a heightened awareness of learning styles and cognitive development theories are ... primary issues that need increased attention. Of particular interest to [them] is the need to gain greater awareness and understanding of learning styles and the integration of that knowledge into instruction planning. ${ }^{3}$

Language is the most cited barrier. ${ }^{4}$ But perhaps rather than see it as such, it would be more helpful to understand the language issue from another perspective that could offer librarians fresh insights on instruction.

Library instruction is known for having incorporated behavioral and cognitive theories of learning. There are other learning theories, however, that library instruction has not paid closer attention to that have a more direct impact on teaching LEP students - theories of second language acquisition and teaching. Indeed, it has been recognized that all teachers of a languageminority population who want to be linguistically and culturally responsive in their teaching must know not only about cross-cultural communication, but about first and second language learning and development, ways of adapting materials and methods, and assessment. ${ }^{5}$ Despite the many examples of librarian-ESL faculty collaboration found in the literature, only a few have discussed or called for the application of ESL theories to library instruction. ${ }^{6}$ Awareness of theories of second language learning and approaches to teaching is vital if librarians are to provide more meaningful instruction to LEP students.

This article summarizes two major language acquisition theories and ESL teaching methods derived from them, and discusses a library instruction model based on them. This model has been used to teach advanced students in the ESL program at Ohio State University. 
However, it need not be limited to just that target group. It can be adapted for teaching any other population because it uses principles applicable to many other learning situations. The Appendix provides a checklist that can help librarians with class preparation.

\section{LAnguage ACQUiSition Theories And LANguage Teaching}

Theories of language acquisition fall into three main categories, and each has methods and practices of second language teaching derived from it. The two that dominated linguistic debates for much of the 1960s and 1970s are behaviorism, as outlined by B.F. Skinner in Verbal Behavior, ${ }^{7}$ and innatism, whose chief proponent was Noam Chomsky. Since the 1980s, interactionist theory has been more widely applied to teaching. Given that behaviorism is not new to library instruction, this article will discuss only the last two theories.

\section{Innatist Theory}

Innatists do not see language development as being influenced by responses to environmental stimuli as behaviorists do. Chomsky theorizes that all humans are born with a "language acquisition device" (LAD) that provides them with the innate ability to process linguistic rules. According to this theory, children do not simply mimic the sounds they hear when learning a language. Instead, they piece together the grammar of the language as they go through the natural developmental process. However, the acquisition device is "turned off" once the critical period for language learning has passed, which is the reason why innatists believe it is more difficult to learn a language in adulthood. Chomsky also established the dichotomy between linguistic competence, the knowledge of the underlying system of grammatical rules (gained through the use of the LAD), and performance, the overt manifestation of the rules through communication.

Stephen Krashen ${ }^{8}$ built on Chomsky's notion of competence in postulating his model of second language acquisition. His Monitor Model is widely regarded as very influential in the area of second language learning and teaching, especially in the sheltered instruction movement. Krashen delineates five core hypotheses, one of which distinguishes between the dual processes of "acquisition" and "learning" necessary for internalizing a new language. The former is narrowly defined as a subconscious process by which learners pick up a language, as in the Chomskyan concept of how children acquire their first language; the acquired knowledge then makes it possible for the learner to produce language. Learning, on the other hand, is the more conscious attempt to know about the structure and workings of a language, often done in formal teaching settings (as in Chomsky's competence). Learned material, therefore, helps the student monitor the correctness of acquired knowledge in language production (or performance). This constitutes his Monitor Hypothesis.

\section{"Learned material, therefore, helps the student monitor the correctness of acquired knowledge in language production (or performance)."}


Other hypotheses in Krashen's Monitor Model include the Affective Filter hypothesis in which he states that learning occurs when there is no barrier (e.g., environmental, social, and attitudinal) affecting the intake of new information. It is only when the filter is "down" that new information is efficiently processed and integrated into the learner's knowledge base. This new information that needs to be processed and understood by the learner is what forms part of his Comprehensible Input hypothesis discussed by Lia Kamhi-Stein and Alan Stein. ${ }^{9}$ Krashen postulates that input must build on what the learner already knows (input +1 ) and that once the learner deconstructs and understands it, the output or performance should reflect that comprehension. Meaning, therefore, has to be processed, and sometimes negotiated, by the participants in the communicative act before the input becomes comprehensible and for output to be judged as "correct."

Current ESL teaching practice has incorporated various aspects of innatism. With the view that native speakers first "absorb" the underlying grammatical rules of the language spoken around them, initially de-emphasizing the overt teaching of linguistic rules and proper speech production typifies the innatist-inspired, second-language classroom. Increasingly, too, learners and the factors affecting their learning began receiving more attention during the 1980s. Learnercentered contexts with an emphasis on the affective domain and the idea that students bring some other knowledge base and experience to the class thus gave new direction to language pedagogy.

\section{Interactionist Theory}

The second theory of second language acquisition discussed in this article, interactionism, focuses more on the use of language in communicative acts, on the functions of language, and its use in various contexts. Interactionists believe that as native speakers communicate with language learners, they modify their language to accommodate the learners' communicative proficiency and level of understanding. Learners, too, use their budding language skills as they communicate back, with both groups negotiating meaning if there happens to be some unclear message. Some types of learner error, therefore, can be self-corrected in this exchange, while others would have to be overtly taught. Dell Hymes ${ }^{10}$ hypothesizes that, through this act of interacting and communicating, learners gain language proficiency, or to use his term, communicative competence (to contrast with Chomsky's linguistic competence). His view is that knowing the grammatical rules of a language is not enough because it does not necessarily translate into the ability to communicate effectively using different registers, or in all contexts.

Curricula based on the interactionist, communicative approach to language teaching stress the use of authentic, real-life language materials in the classroom, rather than simulated, decontextualized ones, and the creating of situations through which meaningful interaction enhances learning. The instructor does not control learning, but acts as a facilitator. Using collaborative learning groups, teaching all aspects of communication in an integrated skills class, and making students respond personally to texts read (to stimulate the receptive and productive use of language), are examples of practices that have responded to the communicative approach and that have continued to gain popularity in the ESL classroom. 


\section{SECOND LANGUAGE AND INFORMATION LITERACY INSTRUCTION: MAKING THE CONNECTION}

The question that may now arise is how this knowledge would be of use to instruction librarians. The rest of the article examines practical ways in which knowledge of second language learning and teaching can help structure information literacy instruction. The instructional model discussed combines aspects of Krashen's innatist Monitor Model with interactionist characteristics. It also incorporates the five factors that most applied linguists believe impact the way a language is learned: social context, learner characteristics, learning conditions, learning process, and learning outcomes.

Social context here refers to, for example, the general atmosphere of the learning environment, the classroom dynamics, opportunities for student-student and student-instructor interaction, and the students' perception of the instructor's commitment to their learning. The characteristics of learners, the second factor, cover a whole range of personal, social, and attitudinal aspects. These include the average age of students; their previous and/or current educational, professional or life experiences; their proficiency levels in language; technology and library use; and their motivation for learning. The total of those aspects that fall outside the

Figure 1 Factors That Influence Learning

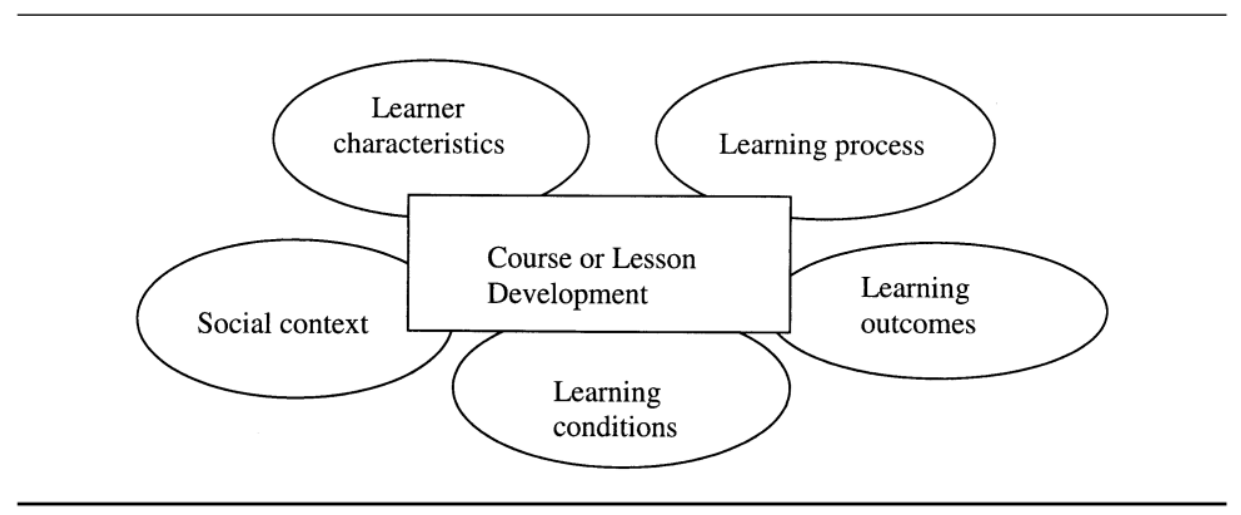

personal and social contexts, but that also impact the learning experience, are what constitute the learning conditions. These could range from the physical conditions of the classroom (e.g., big or small, hot or cold, and adequate and functioning equipment) to what an individual instructor does to enhance learning - clear teaching objectives, well-designed materials, clear transmission of new information, or the point of entry into new material. The learning process simply refers to the various ways through which students prefer to learn, the strategies they employ to do so, and the mental operations they need to complete certain tasks. When all of these other characteristics have been combined, the fifth factor, outcomes of the learning experience and the postinstruction proficiency level of students, can then be assessed.

However, there are various opinions on how these five factors, individually or combined, affect successful learning. ${ }^{11}$ With regard to lesson or course development, Figure 1 depicts how they can form the baseline that instructors should be aware of. Depending on the unique situation of each class or program, librarians can create their own connections between the factors and choose to highlight or de-emphasize any of them. 
These five factors have been matched with features of Krashen's Monitor Model to produce four cells, as shown in the instructional model in Figure 2. This matching of factors and features has been done to make it much easier for librarians to plan a class/course and to design activities that reinforce or tools that measure learning. Double-headed arrows have been used to indicate that the ideal linear progression in the teaching-learning process rarely happens; the twoway flow depicts the influence of one component of the model on the adjacent one and the often necessary retracing of steps in the teaching-learning process. Each cell of the model will be discussed individually.

\section{The Affective Filter/Social Context}

As stated earlier, a low affective filter helps determine success in learning. The social context in which teaching takes place should, therefore, provide the low affective filter that moves input on to the next level. The non-threatening atmosphere has to be felt the moment students walk into the class, and it is expected that the filter gets lower as the class progresses. As Cynthia Mae Helms found from the ESL students she surveyed, their ideal learning environment should have a "small student-teacher ratio, coupled with the teachers' enthusiasm, patience, warm reception, and personalized acceptance and concern for each student." 2 This seems to paint the picture of a typical ESL classroom, a situation in which many LEP students feel comfortable and want replicated in other learning contexts. Therefore, the welcoming smile, the introduction, the allaying of fears, and appropriate ice-breaker activities will all help lower

Figure 2 Instructional Model

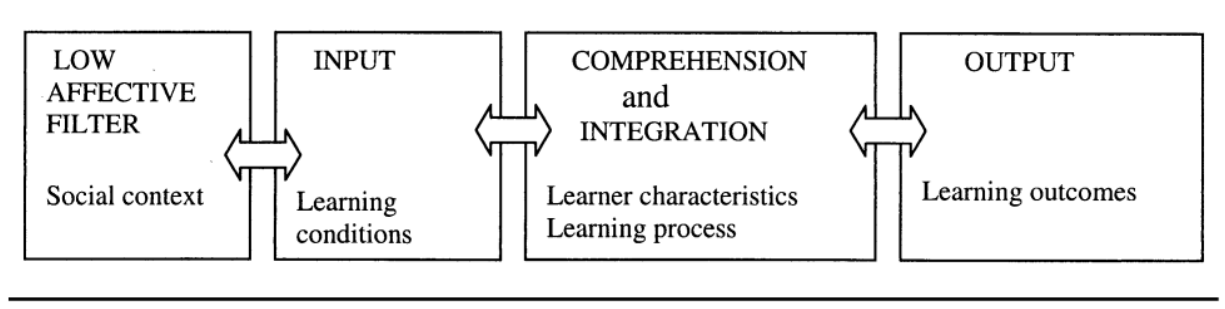

the filter and effect the smooth intake of new information. As Bobbie Collins, Constance Mellon, and Sally Young ${ }^{13}$ in their discussion of beginning researchers' anxiety reiterate, "[b]efore the work of instruction can begin, attitudes [of students and teachers] must be changed, reassurances must be offered, and anxieties must be allayed."

Some questions to keep in mind when planning the class include how to create a learning community in which no student remains ill at ease, and all feel respected; how to make students feel the librarian will not judge their "inadequate" language skills; how to respond to their language/computer/IL-related "errors;" and how much one-on-one instructor-student interaction there will be. The answers to these questions go a long way in creating an atmosphere in which the students will feel comfortable during the learning encounter. 


\section{Input/Learning Conditions}

In this instructional model, the library concepts and skills to be taught represent the input. However, because learning conditions significantly impact how input is made comprehensible, librarians must pay considerable attention to the non-social contexts that would enhance the way LEP students process input. Discussed below are three examples of conditions that are conducive to learning.

\section{Instructor's Language}

As discussed earlier in this article, librarians consider language an important barrier to learning for LEP students. One popular suggestion is that speaking slowly makes understanding easier for LEP students. True, most ESL teachers do use some form of modified teacher-talk when communicating with their students, but they do so less with advanced level students, the same students that librarians generally instruct. Modifications such as slower rate of speech or exaggerated articulation rarely form part of the advanced level teacher's repertoire. Normal rate, which mirrors authentic, real world communication, is what is preferred. Based on her research, Eileen Blau ${ }^{14}$ concludes that slowing down or simplifying syntax may not be very useful for second language learners. To enhance learner comprehension, it is more advisable to use longer pauses between semantic groups so that students can process the whole meaning and not spend too much time deciphering individual words or sentences. Additionally, to aid comprehension, instructors generally try to enunciate more clearly, and opt for restatement of ideas and reformulation of sentences rather than repetition.

\section{Mode of Instruction}

The underlying principles that support librarians' philosophy of teaching and how they think knowledge can be effectively transmitted both have a direct impact on how they plan a session and design ways to measure output. For example, if they believe that students learn by doing, instructors would create a learner-centered environment. They could, for example, design activities that encourage students to conduct searches and reflect on the whys and hows of results. In cases in which classes are held in a teaching lab, a good exercise would be to have different groups conduct a search on the same topic in different ways (e.g., subject vs. keyword, substituting synonyms) and then discuss their results with the class. While learning the library concept, LEP students will also use their language skills as well as critical thinking skills. Without overtly being a language teacher, the librarian would have provided an opportunity for them to build on their oral skills and perhaps to incorporate new vocabulary. This exercise underscores the inter-actionist view that language (and perhaps all) learning occurs through communication; it also makes use of the collaborative method of learning that is central to the communicative approach and reinforces the "English across the curriculum" concept.

\section{Building on Prior Knowledge and Experiences}

Schema theory stresses the importance of making connections between material already known and new information. For library instruction where placement testing is not the norm, it is always a good idea to know the various proficiency levels of LEP students. For language (oral 
and written) proficiency, librarians can get their institutions' ESL program requirements and course descriptions to determine the general level of a class. Additionally, asking ESL teachers to poll the class on their pre-U.S. and U.S. library experience will give the librarian a sense of what students already know and will be helpful in determining the starting point for a lesson.

If these cannot be done in time for the class, such information can be elicited in various ways while students are in class, although previously designed materials would have to be adapted as the class progresses. Ice-breakers can be used in such instances to perform a dual role. Also, simple activities based on, for example, the use of the Yellow Pages (e.g., looking for a local travel agent to plan a trip home) are useful for knowing how well students can formulate search concepts and terms, navigate the directory, or make decisions on relevance and appropriateness. They may have personally made all their travel plans from their home country to the United States, so that old knowledge could be built on in the Yellow Pages exercise and taken further to teaching search strategies. Another example is to ask students to describe the steps they use to write an essay (many advanced level students will be familiar with the writing process), which the librarian can put up on the board. The librarian can refer to these points and match them with steps in the library research process. Thus, meaningful interaction between known and new information is promoted, and the integration of the latter into the existing base and possibilities for future application in other schemas are enhanced.

Additionally, making the connection between searching for information that fills more than one personal need (to spend time in their home countries, or do well on a paper) would make students want to invest more in the enterprise. Indeed, it is only when new information "matters to learners, includes their values and purposes, and contributes to a critical consciousness" 15 that meaning is enhanced and new information incorporated into their knowledge base.

\section{Comprehension and Integration/Learner Characteristics and Learning Process}

Creating all the "right" learning conditions should, theoretically, lead to successful learning. But to ensure that such learning takes place, or that input is comprehended and integrated into the learner's existing knowledge, characteristics of the learners and their ways of learning are also important considerations. Some learner characteristics librarians need to be aware of include the average age and prior experiences of the students (helpful to determine relevant topics or interests to be used as examples), their computer and/or language skills, and knowledge of their preferred learning styles. With regard to the latter, many studies indicate LEP students' inclination toward the kin-esthetic and tactile, ${ }^{16}$ but it will not hurt to combine as many opportunities for incorporating various styles because learners tend to operate along a continuum of styles in response to the challenges presented. The visual, in particular, is one that can be highly beneficial to second language learners, so PowerPoint presentations (with handouts, to preempt copying from the screen) and other visual representations, such as concept maps, coupled with hands-on exercises, can go a long way in reinforcing input. 


"So when, for example,
teachers think that LEP
students are reluctant to speak
in class, they could be using
either the metacognitive
strategy of delayed production
or learning initially through
listening."

Connected with learning styles are the strategies students use to aid in the learning of new information. These are also crucial to the successful integration of that material into existing knowledge. For LEP students in one study, over 20 strategies were identified, and these were categorized into three broad types: metacognitive, cognitive, and socioaffective. ${ }^{17}$ So when, for example, teachers think that LEP students are reluctant to speak in class, they could be using either the meta-cognitive strategy of delayed production or learning initially through listening. These strategies are, of course, what constitute the central premise of innatism. Note taking, transfer (of old knowledge to new learning situation), elaboration, or linking new information to existing ones are some of the cognitive strategies students sometimes use. Working collaboratively, and seeking clarification from instructor or peers, are ways in which they use strategies of social mediation. This latter strategy reiterates the negotiation of meaning that is at the heart of interactionism.

In short, input should be clearly articulated and demonstrated by using a variety of methods; it should be systematically modified or clarified through questioning and reformulation by both parties, and must it interact with learners' prior knowledge and experience so that comprehension and integration are facilitated. If, as suggested by Kahmi-Stein and Stein, ${ }^{18}$ that teaching information competency for LEP students is akin to teaching them a third language, then language learning strategies should work well here. Tips on what might stimulate the use of diverse learning strategies include creating links through analogies, creating handouts and worksheets, and using visual representations. Games, often used by ESL instructors as a learning tool, can also have some value in the information literacy classroom.

\section{Output/Learning Outcomes}

Once comprehended, the new knowledge has to either reinforce prior beliefs or transform current ideas and practice. Unfortunately, innatism in general, and Krashen's Monitor Model in particular, do not pay much attention to output and its evaluation. Similarly, the large body of works on library instruction has only a small subset that focuses on evaluation. Studies measuring how much learning has occurred in the one-time session, or how it has transformed the learner, are not easily found in the literature because "the evaluation of library instruction tends to focus upon attendees' perceptions of the librarian's performance." ${ }^{19}$ As such, librarians rarely have a way of knowing how much students have learned. The situation is even more difficult for assessing instruction to LEP students; there is hardly any material in the literature that deals with assessing the output of LEP students. 


\section{"Summative assessment is, therefore, of not much value in \\ one-shot instruction sessions \\ because it does not allow for the feedback necessary for effective learning."}

In general, post-instruction assessment is what is more common in library instruction. This type of assessment is summative and is typically used to measure learning for grade purposes. Summative assessment is, therefore, of not much value in one-shot instruction sessions because it does not allow for the feedback necessary for effective learning. By preferring to use summative assessment, librarians "lose" additional teaching moments where material can be retaught and reinforced and would have to seize the moment when, or if ever, those students make their next visit to the reference desk.

Classroom assessment provides a better alternative because it is well suited for one-time instruction. It is formative in that it provides "information on what, how much, and how well students are learning" [emphasis added] during a teaching situation, and it prepares them for "subsequent graded evaluations [that is, summative] and in the world beyond the classroom." 20 Instructors can get immediate feedback from this type of assessment, and it can be done at various points during the lesson. For example, in a hands-on setting, asking students to perform a particular search is one quick way to judge how well they can use the resource. While students are performing the task, the instructor can walk unobtrusively around, noting down some of the things observed. ${ }^{21}$ Based on the observed feedback, the instructor can determine whether or not to re-teach or clarify imprecise points. In other examples, students can be presented with a large set of hits and asked to come up with ways of bringing it to a manageable list of relevant items (Angelo and Cross" "problem recognition task") or to determine why there are so many hits (Angelo and Cross' "What's the principle"). Such exercises are mutually beneficial to student and instructor because they enable both to learn more and to teach better, respectively.

By letting learners "interact" and "communicate" with the new information (as interactionist theory suggests), LEP students will be able to use the new skill and to have opportunities for "negotiating meaning" with concepts and resources.

\section{CONCLUSION}

Just as innatist and interactionist acquisition theories have profoundly changed second language teaching, their impact can also spill over into library instruction. A basic understanding of second language teaching theories seems fundamental to improving librarians' ability to teach better and to helping LEP students learn more effectively. 


\section{"Just as innatist and interactionist acquisition theories have profoundly changed second language teaching, their impact can also spill over into library instruction."}

Most of the sample activities cited here are not new and have been referred to in the literature, but by discussing them in the light of ESL research and pedagogy, their use in library instruction is strengthened. The model presented is intended to give instruction librarians a concrete example of how applying insights from this area of research and practice can help them design a course that is more linguistically, socially, and culturally responsive and thereby create a more rounded learning experience for LEP students. By encouraging connections between new and known material, by bringing library instruction in closer harmony with the language instruction methods more familiar to students, and by helping students understand that information and language skills profoundly impact both their academic success and personal lives, librarians will be doing a great service. Perhaps, this will reduce their feeling of isolation in non-ESL classes and make them more active participants in the learning project. They no longer need be seen as "strangers in academia.",22

\section{APPENDIX}

\section{Checklist for Course Preparation and Instruction}

\section{Social Context}

$\square \quad$ Create and maintain a welcoming atmosphere

- Allow for instructor-student interaction

- Allow for student-student interaction (e.g., in pairs, groups)

口 Use humor

๑ Extend invitation for additional contact

\section{Communication}

$\square \quad$ Be aware of students' linguistic proficiency

- Speak clearly

- Pause strategically to facilitate comprehension

$\square \quad$ Give clear and precise directions

- Use clear and relevant examples

- Give clear definitions of words and concepts

$\checkmark$ Explain idiomatic expressions when used

- Use non-verbal gestures/expressions to accompany verbal communication

- Encourage student-student question/answer 
- Encourage student-instructor questions

- Restate, re-teach, and reinforce

\section{Styles and Strategies}

- Present concepts in a variety of ways

$\square \quad$ Incorporate active learning

$\square \quad$ Use a variety of teaching formats

Provide opportunities for use of various learning strategies

$\square \quad$ Observe and provide immediate feedback

\section{Cultural Context}

$\square \quad$ Be aware of age, gender, country of origin, and so forth

Include elements from different cultures in examples

- Integrate students' other knowledge and experience

$\square \quad$ Learn about different cultures

$\square \quad$ Respect students' points of view

\section{NOTES AND REFERENCES}

1. I prefer this term over the more frequently used "foreign" or "international" students because it includes a new category of students who do not fit the profile of these other terms - new immigrants with low language skills.

2. Diane DiMartino \& Lucinda R. Zoe, "International Students and the Library: New Tools, New Users, and New Instruction," in Teaching the New Library to Today's Users, edited by Trudi E. Jacobson \& Helene C. Williams (New York: Neal-Schuman, 2000), pp. 17-43.

3. DiMartino and Zoe, "International Students," p. 20.

4. For a list of 18 articles citing the language barrier as a problem, see, for example, Allen Natowitz, "International Students in U.S. Academic Libraries: Recent Concerns and Trends," Research Strategies 13 (Winter 1995): 4 16.

5. JoAnn (Jodi) Crandall, "The Role of the University in Preparing Teachers for a Linguistically Diverse Society," in Handbook of Undergraduate Second Language Education, edited by Judith Rosenthal (Mahwah, NJ: Lawrence Erlbaum, 2000), 279-299.

6. See, for example, Molly O'Hara, "Bibliographic Instruction for Foreign Students," in Academic Libraries: Myths and Realities, edited by Susan C. Dodson \& Gary L. Menges (Chicago: Association of College and Research Libraries, 1984), pp. 230-233; Lia D. Kamhi-Stein \& Alan Paul Stein, "Teaching Information Competency as a Third Language," Reference and User Services Quarterly 38 (1998): 173-179; DiMartino and Zoe, "International Students."

7. B.F. Skinner, Verbal Behavior (New York: Appleton-Century, 1957).

8. Stephen D. Krashen, Second Language Acquisition and Second Language Learning (Oxford, England: Oxford University Press, 1981).

9. Kahmi-Stein and Stein, "Teaching Information Competency."

10. Dell Hymes, "On Communicative Competence," in Sociolinguistics, edited by J. B. Pride \& Janet Holmes (Harmondsworth, England: Penguin, 1972), pp. 269-293.

11. H.H. Stern, Fundamental Concepts of Language Teaching (Oxford, England:Oxford University Press, 1984), pp. 337-341.

12. Cynthia Mae Helms, "Reaching out to the International Students through Bibliographic Instruction," The Reference Librarian 50/51 (1995): 295-307.

13. Bobbie L. Collins, Constance A. Mellon, \& Sally B. Young, "The Needs and Feelings of Beginning Researchers," in Bibliographic Instruction, edited by Constance A. Mellon (Littleton, CO: Libraries Unlimited, 1987), pp. 73-84.

14. Eileen K. Blau, "The Effect of Syntax, Speed, and Pauses on Listening Comprehension," TESOL Quarterly 24 
(Winter, 1990): 746-753.

15. Raymond J. Wlodkski \& Margery B. Ginsberg, Diversity and Motivation (San Francisco, CA: Jossey-Bass, 1995), p. 164.

16. Joy M. Reid, “The Learning Style Preferences of ESL Students,” TESOL Quarterly 21 (March 1987): 87-111.

17. J. Michael O’Malley, Anna U. Chamot, Gloria Stewner-Manzanares, Rocco P Russo, \& Lisa Kupper, "Learning Strategy Applications with Students of English as a Second Language," TESOL Quarterly 19 (1985): 557-584.

18. Kahmi-Stein \& Stein, "Teaching Information Competency."

19. Patrick Ragains, "Evaluation of Academic Librarians' Instructional Performance: Report of a National Survey," Research Strategies 153 (1997): 159-175.

20. Thomas A. Angelo \& K. Patricia Cross, Classroom Assessment Techniques (San Francisco, CA: Jossey-Bass, 1993), p. 5.

21. Bonnie Campbell Hill, Cynthia Ruptic, \& Lisa Norwick, Classroom-based Assessment (Norwood, MA: Christopher-Gordon Publishers, 1998).

22. Vivian Zamel, "Strangers in Academia: The Experiences of Faculty and ESL Students Across the Curriculum," College Composition and Communication 46 (December 1995): 506-521. 